\title{
TESTOSTERONE AND DEHYDROEPIANDROSTERONE IN THE EPIDIDYMIS OF THE RABBIT
}

\author{
A. I. FRANKEL* AND K. B. EIK-NES $\dagger$ \\ Department of Biological Chemistry, University of Utah College of Medicine, \\ Salt Lake City, Utah 84112
}

(Received 10th Fanuary 1970, revised 22nd May 1970)

\begin{abstract}
Summary. Testosterone and dehydroepiandrosterone were present in higher concentration in the caput than in the cauda epididymidis of the rabbit. Although testosterone levels were higher in the testis than in the caput epididymidis, dehydroepiandrosterone levels were not. This distribution of steroids could help explain data recording localization of sperm fertility in this organ.
\end{abstract}

\section{INTRODUCTION}

Although it has been known for some time that testosterone is necessary for the maintenance of the cellular and secretory integrity of the mammalian epididymis (Bishop, 1961; Mann, 1964), data on levels of steroids in this organ are recent. The first direct evidence for the presence of steroids in this tissue was published by Frankel \& Eik-Nes (1968), who found both testosterone and dehydroepiandrosterone (DHEA) in the rabbit epididymis. Soon afterwards, White \& Hudson (1968) reported that the same steroids could be detected in fluid from the caput epididymidis of the ram. Earlier, Steeno, Schirren, Heyns \& DeMoor (1966) described the presence of DHEA-sulphate in human seminal fluid. Inano, Machino \& Tamaoki (1969) described the synthesis of testosterone in vitro from radioactive precursors by rat epididymides.

None of these studies dealt with the possibility that the epididymis might have different steroid concentrations in its various segments. It has been known for some time that spermatozoa in the proximal epididymis of the guineapig lack the ability to fertilize (Young, 1931); the same observations have been made on spermatozoa from the caput epididymidis of the rabbit (OrgebinCrist, 1967, 1969; Bedford, 1967; Paŭfler \& Foote, 1968). In the light of the above findings, it seemed important to find out whether or not there were differences in steroid levels between the caput and cauda epididymidis. Such differences could explain why the environment in the caput epididymidis is unfavourable to sperm maturation.

* Present address: Department of Biology, State University of New York at Binghamton, Binghamton, New York 13901 .

† Present address: Division of Biochemistry and Physiology of Reproduction, University of Southern California School of Medicine, Los Angeles, California 90033. 


\section{MATERIAL AND METHODS}

New Zealand white rabbits were anaesthetized with sodium pentobarbital given intravenously. One testis with its epididymis was removed, and the organs were separated from each other immediately. The animal was then injected intravenously either with $0.9 \%$ sodium chloride or with $500 \mathrm{U}$ of human chorionic gonadotrophin (HCG) in saline. The other testis with its epididymis was removed 30 min later.

Approximately $500 \mathrm{mg}$ testicular tissue were cut off and weighed. Caput and cauda epididymidis were removed intact and weighed. All tissues were placed in $0.9 \%$ sodium chloride solution, frozen immediately and stored at $-20^{\circ} \mathrm{C}$ until processed for steroids. The caput epididymidis was distinguished from the cauda epididymidis on the basis of the classification by Nicander (1957).

Before steroid analysis, $\left[1,2-{ }^{3} \mathrm{H}\right]$ testosterone $(36,000 \mathrm{~d} / \mathrm{min}$, specific activity of $36 \mathrm{Ci} / \mathrm{mmol})$ and $\left[7-{ }^{3} \mathrm{H}\right]$ dehydroepiandrosterone $(34,000 \mathrm{~d} / \mathrm{min}$, specific activity of $14.4 \mathrm{Gi} / \mathrm{mmol}$ ) were added to the samples to serve as radioactive tracers from which to determine steroid recovery.

The tissue was homogenized in $0.9 \%$ sodium chloride solution and the homogenate was extracted with ether:chloroform $(4: 1, \mathrm{v}: \mathrm{v})$. Excess fat in the extract was removed by the technique of Farrell, Royce, Rauschkolb \& Hirschmann (1954) and the residue was chromatographed successively (without drying on paper) in the solvent system, hexane:formamide, and then hexane: benzene $(1: 1, \mathrm{v}: \mathrm{v})$ formamide. After being dried, the paper was scanned for radioactivity, and the radioactive peaks corresponding in chromatographic behaviour either to authentic testosterone or to authentic dehydroepiandrosterone were eluted with $30 \mathrm{ml}$ highly purified methanol (Frankel \& Nalbandov, 1966).

The testosterone fraction was processed by the method of Brownie, van der Molen, Nishizawa \& Eik-Nes (1964), and the dehydroepiandrosterone fraction by the method of Wasserman \& Eik-Nes (1968). Gas-phase chromatography was effected with a Barber-Colman Model 10 gas-chromatograph using a $1 \%$ XE-60 column. In the testosterone assay, the chloroacetate of $20 \beta$-reduced progesterone was used as an internal standard (Resko \& Eik-Nes, 1966). The standardization of the electron capture cell in the dehydroepiandrosterone assay was as outlined by Rapp \& Eik-Nes (1966); a standard amount of authentic DHEA 17-pentafluorophenylhydrazone was injected immediately after the sample peak of this steroid was detected. One nanogram of pure DHEA 17-pentafluorophenylhydrazone gave a peak of approximately $10 \mathrm{~cm}^{2}$ or half scale on the 11-inch recorder when chromatographed under the conditions of our DHEA assay.

Differences between steroid concentrations in epididymal segments were examined by non-parametric statistics based on a comparison of data from all twenty tissue samples assayed from both treated and untreated animals, although lower significant differences were present in the ten untreated tissues. The effect of HCG upon steroid concentrations was tested by analysis of variance, where the final values from treatment with saline or HCG were compared. In these calculations, adjustment for the initial values was carried out by analysis of co-variance. 


\section{RESULTS}

The testosterone concentrations (Table 1) in the testis were, as expected, significantly higher than in the caput $(P<0.001)$ and cauda epididymidis $(P<0.001)$. Testosterone in the testis increased significantly $(P<0.02)$ following treatment of the rabbit with HCG. Although concentrations of testosterone in both the caput and cauda epididymidis increase as a result of HCG treatment, the increases were not significant. Unexpectedly, testosterone levels were five to ten times higher in the caput epididymidis as compared to the cauda epididymidis $(P<0.001)$.

TABLE 1

MEAN TESTOSTERONE CONCENTRATION IN TESTIS, GAPUT EPIDIDYMIDIS AND GAUDA EPIDIDYMIDIS OF RABBIT

\begin{tabular}{c|c|c|c|c}
\hline \multirow{2}{*}{$\begin{array}{c}\text { No. of } \\
\text { animals }\end{array}$} & & & \multicolumn{2}{|c}{ Epididymis } \\
\hline \multirow{2}{*}{5} & Treatment & Testis & Caput & Cauda \\
\cline { 3 - 5 } 5 & None & $150 \cdot 7 \pm 53 \cdot 3 *$ & $31 \cdot 1 \pm 9 \cdot 4$ & $2 \cdot 9 \pm 1 \cdot 3$ \\
& Saline & $182 \cdot 3 \pm 109 \cdot 5$ & $30 \cdot 1 \pm 10 \cdot 9$ & $2 \cdot 8 \pm 1 \cdot 3$ \\
& None & $144 \cdot 9 \pm 55 \cdot 3$ & $19 \cdot 4 \pm 3 \cdot 8$ & $3 \cdot 5 \pm 1 \cdot 6$ \\
& HGG & $527 \cdot 8 \pm 150 \cdot 1$ & $27 \cdot 2 \pm 10 \cdot 7$ & $5 \cdot 5 \pm 2 \cdot 0$ \\
\hline
\end{tabular}

* Results are presented as nanograms testosterone/500 mg of tissue \pm one standard error of the mean.

TABLE 2

DEHYDROEPIANDROSTERONE CONGENTRATION IN TESTIS, CAPUT EPIDIDYMIDIS AND GAUDA EPIDIDYMIDIS OF RABBIT

\begin{tabular}{c|c|c|c|c}
\hline \multirow{2}{*}{$\begin{array}{c}\text { No. of } \\
\text { animals }\end{array}$} & Treatment & Testis & \multicolumn{2}{|c}{ Epididymis } \\
\hline \multirow{2}{*}{5} & None & $11 \cdot 8 \pm 4 \cdot 1 *$ & \multicolumn{1}{|c}{ Caput } & \multicolumn{1}{c}{ Cauda } \\
\cline { 2 - 4 } 5 & Saline & $9 \cdot 7 \pm 6 \cdot 6$ & $7 \cdot 2 \pm 7 \cdot 6$ & $0 \cdot 8 \pm 0 \cdot 4$ \\
5 & None & $3 \cdot 4 \pm 0 \cdot 9$ & $5 \cdot 1 \pm 0 \cdot 7$ & $2 \cdot 3 \pm 0.5$ \\
& HCG & $16 \cdot 0 \pm 6 \cdot 5$ & $5 \cdot 9 \pm 0 \cdot 6$ & $2 \cdot 4 \pm 0 \cdot 4$ \\
& & & & \\
\hline
\end{tabular}

* Results are presented as nanograms DHEA/500 mg of tissue \pm one standard error of the mean.

Concentrations of DHEA (Table 2) in the testis were much lower than those of testosterone. The DHEA levels in the testis rose, but not significantly, following HGG administration. Once again, the DHEA levels in the caput were significantly greater than those in the cauda epididymidis $(P<0.001)$. There was no significant difference between DHEA levels in the testis and DHEA levels in the caput epididymidis. Of the samples assayed from animals not stimulated by HCG, the DHEA concentration in the caput epididymidis was actually higher than that of the testis in eleven out of fifteen experiments. 
DHEA levels in the testis were significantly higher than those in the cauda epididymidis $(P<0 \cdot 02)$.

\section{DISCUSSION}

The high levels of testosterone in the caput epididymidis of the rabbit are of interest in the light of the low fertility of spermatozoa in the caput. Testosterone can bind to spermatozoa (Ericsson, Cornette \& Buthala, 1967) and will also suppresstheir oxygen uptake (Mounib, 1964). It is possible that, while testosterone is essential to epididymal function, it is also inhibitory to sperm maturation in this tissue. Since relatively few spermatozoa are present in the caput epididymidis compared to the cauda, the concentration of steroids/spermatozoon in this latter part of the organ is much lower than indicated by the data of Tables 1 and 2 .

These comments could also apply to the relatively high concentration of DHEA in the epididymis. DHEA may be considered a potential androgen (Prunty, 1966), although its effect upon sperm function has never been reported. It is well established that DHEA is a substrate for the formation in vitro of testosterone in the rabbit testis (Hall, Sozer \& Eik-Nes, 1964), although conversion in vitro of DHEA to testosterone in the rabbit epididymis does not take place (Frankel \& Eik-Nes, 1968).

There is little reason to believe that any of the epididymal testosterone is derived from other sources than the testis. We have recently observed that no testosterone is synthesized in vitro by epididymal slices (rabbit) from substrates like acetate, cholesterol, dehydroepiandrosterone, pregnenolone or progesterone, nor was there any instance of such slices transforming a $\Delta^{5}$-3-hydroxy steroid to a $\Delta^{4}$-3-keto steroid (Frankel \& Eik-Nes, 1970). There is, however, strong evidence to suggest that some of the dehydroepiandrosterone present in the epididymis may be synthesized locally in this organ, since epididymal slices (rabbit) will transform pregnenolone to 17-hydroxypregnenolone and dehydroepiandrosterone (Frankel \& Eik-Nes, 1968). This observation might explain the relatively high concentration of DHEA in the caput epididymidis.

Although spermatozoa are known to bind (Ericsson et al., 1967) and contain (Dirscherl \& Breuer, 1963), as well as metabolize (Seamark \& White, 1964) steroids, we do not attribute any rôle of spermatozoa to the formation of epididymal DHEA or testosterone. If the mechanism by which the caput epididymidis achieves higher DHEA concentrations than the cauda were due to the spermatozoa, then the sperm numbers should be higher in the caput than in the cauda epididymidis. This is, indeed, not the case. In addition, freshly ejaculated rabbit spermatozoa have no ability to transform radioactive pregnenolone either to 17-hydroxypregnenolone or to the radioactive DHEA (Frankel \& Eik-Nes, 1970).

\section{AGKNOWLEDGMENTS}

We thank Miss Elna Kristensen for technical assistance. This work was supported in part by USPHS Training Grant T01 CA 5000, USPHS Research Grant AM 06651, and USPHS Research Grant 1 RO HDO4081-01. 


\section{REFERENGES}

BEDFord, J. M. (1967) Effects of duct ligation on the fertilizing ability of spermatozoa from different regions of the rabbit epididymis. F. exp. Zool. 166, 271.

Bissop, D. W. (1961) Biology of spermatozoa. In: Sex and Internal Secretions, Vol. II, pp. 707-796. Ed. W. C. Young. Williams \& Wilkins, Baltimore.

Brownie, A. C., van der Molen, H. J., NishizaWa, E. E. \& Eik-Nes, K. B. (1964) Determination of testosterone in human peripheral blood using gas-liquid chromotography with electron capture detection. 7. clin. Endocr. Metab. 24, 1091.

DirscherI, W. \& BREUER, H. (1963) Isolierung von Dehydroepiandrosteron aus menschlichem Sperma. Acta endocr., Copenh. 44, 403.

Ericsson, R. J., Cornette, J. C. \& Buthala, D. A. (1967) Binding of sex steroids to rabbit sperm. Acta endocr., Copenh. 56, 424.

Farreli, G. L., Royce, P. G., Rauschrolb, E. W. \& Hirschmann, H. (1954) Isolation and identification of aldosterone from adrenal venous blood. Proc. Soc. exp. Biol. Med. 87, 141.

Frankel, A. I. \& Eik-Nes, K. B. (1968) Steroidogenesis in vitro of the epididymis of the rabbit. Fedn Proc. Fedn Am. Socs exp. Biol. 27, 624.

Frankel, A. I. \& EIK-Nes, K. B. (1970) The metabolism of steroids in the rabbit epididymis. Endocrinology, (in press).

Frankel, A. I. \& Nalbandov, A. V. (1966) Effect of the evaporation of various solvents upon the stability of corticosterone-1,2- ${ }^{3} \mathrm{H}$ and corticosterone $-4{ }^{14} \mathrm{C}$. Steroids, $8,749$.

Hall, P. F., Sozer, C. C. \& EIK-Nes, K. B. (1964) Formation of dehydroepiandrosterone during in vivo and in vitro biosynthesis of testosterone by testicular tissue. Endocrinology, 74, 35 .

Inano, H., Machino, A. \& Tamaoki, B. (1969) In vitro metabolism of steroid hormones by cell-free homogenates of epididymides of adult rats. Endocrinology, 84, 997.

ManN, T. (1964) The biochemistry of semen and of the male reproductive tract, p. 53. Methuen, London.

Mounis, M. S. (1964) Effects of certain hormones on the metabolism of bull spermatozoa. Acta endocr., Copenh. 45, 631 .

NICANDER, L. (1957) On the regional histology and cytochemistry of the ductus epididymidis in rabbits. Acta morph. neerl.-scand. $1,99$.

Orgebin-Grist, M. C. (1967) Sperm maturation in rabbit epididymis. Nature, Lond. 216, 816.

Orgebin-Grist, M. C. (1969) Studies on the function of the epididymis. Biol. Reprod. Suppl. 1, 155.

PAürLeR, S. K. \& Foote, R. H. (1968) Morphology, motility and fertility of spermatozoa recovered from different areas of ligated rabbit epididymides. F. Reprod. Fert. 17, 125.

Prunty, F. T. G. (1966) Androgen metabolism in man-some current concepts. Br. med. J. 2, 605.

RAPP, J. P. \& EIK-Nes, K. B. (1966) The effect of front size on electron capture detector sensitivity. 7. Gas Chromatogr. 4, 376.

Resxo, J. A. \& EIK-NEs, K. B. (1966) Diurnal testosterone levels in peripheral plasma of human male subjects. F. clin. Endocr. Metab. 26, 573.

Seamark, R. F. \& White, I. B. (1964) The metabolism of steroid hormones in semen. F. Endocr. 30, 307.

Steeno, O., Schirren, G., Heyns, W. \& DeMoor, P. (1966) Dehydroepiandrosterone in human seminal plasma. 7. clin. Endocr. Metab. 26, 353.

Wasserman, G. F. \& Eik-Nes, K. B. (1968) Gas phase chromatography of androgens in biological samples. In: Gas Phase Chromatography of Steroids, p. 274. Eds. K. B. Eik-Nes and E. C. Horning. Springer, New York.

Whrre, I. G. \& Hudson, B. (1968) The testosterone and dehydroepiandrosterone concentration in fluids of the mammalian male reproductive tract. F. Endocr. 41, 291.

Young, W. C. (1931) A study of the function of the epididymis. III. Functional changes undergone by spermatozoa during their passage through the epididymis and vas deferens in the guinea pig. F. exp. Biol. 8, 151 . 